Journal of

Media, Culture \& Society

\title{
"In the case of Africa in general, there is a tendency to exaggerate,": Representing Mass atrocity Coverage in Africa
}

\begin{tabular}{|r|l|}
\hline Journal: & Media Culture and Society \\
\hline Manuscript ID: & MCS-2014-374 \\
\hline Manuscript Type: & Original Article \\
\hline Keyword: & Representation, Knowledge, Collective Memory, Narrative, Rwanda, Darfur \\
\hline Abstract: & $\begin{array}{l}\text { Based on an analysis of print media and journalists' interviews, this article } \\
\text { examines the representation of atrocity and mass violence in Africa. It } \\
\text { specifically focuses on the atrocities in Darfur and Rwanda and compares } \\
\text { African and western coverage of them. It argues that since representations } \\
\text { (just as the knowledge that anchors them) are highly dependent on one's } \\
\text { social location it is necessary to understand multiple representations of the } \\
\text { same atrocity. Though literature on representation of Africa has been } \\
\text { critical of western representations of Africa, this article argues that } \\
\text { including African representations of the same provides for a more nuanced } \\
\text { understanding. }\end{array}$ \\
\hline
\end{tabular}


Despite the fact that genocides and mass atrocities are social events, sociology seems to lag behind in studying this important subject matter; the few exceptions being Hagan and Rymond-Richmond (2009), Nyseth-Brehm (2014) and Steinmetz (2005, 2008). This dearth of scholarship is even more pronounced on media representations of genocide and mass atrocities with Savelsberg and Nyseth-Brehm $(2012)^{1}$ being the only sociological study on this that I found. Moreover, general scholarship on media representations of mass atrocities and genocide has focused also primarily on western media (Atkinson 1999a, 1999b; Grzyb 2009; Melvern 2006; Thompson 2007) and largely been silent on African representations of the same. This literature has echoed debates over the notions of distinct western versus African knowledge and debate over global versus localised scripts (see for example Ray, 2009; Mody 2010).

Sociology of knowledge tells us that knowledge will reflect the social location of an actor. Berger and Luckmann (1966) and Mannheim (1936) both remind us that one's structural position, social context and social location can and should be presumed to affect how they will view and understand an event. Hence, understanding how knowledge about mass atrocity is constituted and how social events are framed and defined is important. This is even more poignant when analyzing the representations of event such as genocides and mass atrocity in the news. As socialized members of society, journalists' knowledge will, arguably, be representative and anchored upon their societal influences on knowledge (Berger and Luckmann 1966; Durkheim 1961; Lippmann 1922). This necessitates an appreciation of the fact undistorted news is in and of itself not always a tenable goal. ${ }^{2}$ The very act of reproduction requires a distorting of reality (Gans 1979: 305 ; Shapiro 1988: xii). 
Fairclough suggests that texts (in this case news reports) are largely dependent on society and history and the way both provide an order through which to structure discourse (1992:195). This echoes Gamson et al. (1989) and Gans (1979) who argue that the news produced is never neutral and exhibits the beliefs and values of those that produce it. Audiences will therefore consume the news through the idiosyncratic coloration given to it by journalists (Gamson et al. 1989; Mills 1967). However, Hall (1973), Lippmann (1922) and Weimann (2000) remind us that encoded narrative is never a unilateral sign but rather complex milieu and provides the potential to be decoded in multiple ways in manners incongruent with the original intent of the journalists. Audiences do not decode narrative in a homogenous fashion (Gamson et al 1989; Hall 1973; Lippmann 1922). To mitigate this, journalists inscribe within their narratives a preferred reading through the use of already present frames and knowledge structures (Gans 1979 Hall 1973; Tuchman 1978; Weimann 2000).

The narrative genres and structures employed by news organizations and journalists to frame mass atrocity have also been a subject of inquiry by scholars. Fine (2001), Pendas (2006) and Savelsberg and King (2011) show that narrative genres employed by news organizations often focuses on the individual, neglecting larger structural and cultural forces at play. Talking about the Auschwitz trials, Pendas alerts us to the focus on "physiognomy," and "personality," of the "characters" (2006: 261) and the more dramatic aspects of the trials; not necessarily the structural details and processes of the trials. Pendas (2006) further talks about a structural amnesia, which results in events being represented as products of forces beyond human control, like the fluctuations in the weather and having neither context nor relation to global factors (Tuchman, 1978: Weimann 2000). ${ }^{3}$ Frequent repetition narratives conventionalizes them, making them part of taken for granted and sedimented knowledge. Weimann (2000) and Asad (2007) 
highlight this process by examining public attitudes on terrorism and who is or is not considered a terrorist.

\section{The charge of Oversimplification}

Western journalists have been accused of offering simplistic narratives about conflicts and having superficial knowledge about the African continent as a whole. Stereotypical reporting of atrocity in Africa, as based on ancient "tribal hatred," is one of the more common charges (Harrow 2005: 35). Schrader and Endless similarly diagnose a "media-driven Afro-pessimism" (1998: 35) that essentialises African conflicts as ones pitting two monolithic communities against each other in an insatiable quest for blood and anarchy (see also work by Allen and Seaton 1999). This is captured by The New York Times on 10 April 1994 which, referred to Rwanda as embroiled in "tribal warfare", in which the Rwandese were defined as being "bloodthirsty", "savage", with "gangs" engaged in an "orgy" of "terror". This charge of superficiality is not solely from scholars. Some African journalists also seem very distrustful of Western journalists reporting on conflicts in Africa. Consider this statement by an interviewee from a Kenyan news organization:

You know it is Darfur conflict...the Sudan journalist is able to understand a historical...you know to give it a historical context. The western journalists on the other hand will be in a hurry to just look at it as uhm...you know what they are seeing now without that historical perspective [..] secondly, as is the case of their coverage of Africa, in general, there is always a tendency to exaggerate.[Kenyan interviewee]

Considering such criticism, it surprising that two large-scale empirical studies of African media reports on Darfur do find that the there is not a substantial deviation in narrative from western representations as may be expected. Ray’s (2009) analysis of news reports from five countries finds a tendency to oversimplify and racialize the Darfur conflict. Ray finds that the labels used to demarcate "fault lines in [the Darfur] conflict are often the same as those used by 
Western news sources" (2009:172). Mody (2010) reports similar patterns identified in her analysis of African media outlets such as the Mail and Guardian online from South Africa. Here actions of the Janjaweed militias are often described as ethnic cleansing. Additionally, Savelsberg and Nyseth-Brehm (2011) find that western representations of Darfur are not as homogeneous as charged by critics

\section{News on Rwanda and Darfur}

Much has been written about the representations and oversimplification of Rwanda and Darfur (Allen and Seaton 1999; Gruley and Duvall 2012; Grzyb 2010; Hawk 1992; Mamdani 2007). News narratives on atrocity in Africa, more generally, is rooted in what Gruley and Duvall refer to as a "colonialist ethnographic classification [..] which continues to underpin oversimplified representations of global politics" (2012: 39). This narrative seeks to make the unintelligible intelligible by relying on a repository of narrative genres and frames; by repeating them over and over until they gain a currency of their own. As a consequence of this, much like orientalism, narratives on atrocity becomes interwoven within a structure of self-referencing frames employed in conflicts in Africa. Consequently, African atrocities can simultaneously be unknown and inexplicable while being recognizable and comprehensible. This iterative process is what Bhabha (1994) refers to as fixity.

The more unusual and dramatic, Gans (2005) and Bourdieu (1998) argue, the better. Focusing on the dramatic, when it comes to Africa, Atkinson (1999b) argues, is influenced by an assumption that conflict in Africa is inspired by fossilized ethnic and cultural realities. This, incidentally, echoes fears of a periphery devoid of values thought to be important to the centre that Schudson (2011) talks about (for similar arguments see work by Gurley and Duvall 2012; Mamdani 2007; Myers Garth, Thomas Klak and Timothy Koehl 1996; Said 1979, 2008). Fine 
(2001) highlights the role of narratives in making structural aspects of a story more compelling and memorable to the audience. Memorable narratives require simplifying complex issues (such as mass atrocity) into discourse on heroes and villains by creating an ordered narrative that makes it easier for the audience to remember and follow the story. Such narratives glean from common language, available to the journalists, to provide structure for and to frame events; pointing to a reflexive embeddedness of narratives within the contexts in which they are produced and presented (Hall 1973, 2007; Schudson 1989; Tuchman 1978:192; Weimann 2000). This embedded nature of narratives, Mannheim (1936) suggest, leads to different individuals being more likely to interpret events in largely the same ways as long as they are immersed within the same social system. Work by Connerton (1989) and Halbwachs (1992) on memory also suggests that narrative innovation is limited by a reliance of memory to explain present events.

\section{Reporting the context/history of Rwanda and Darfur}

In the Rwanda genocide, the conflict was largely defined as chaotic and lacking any clear political motivations by newspapers in the US such as the New York Times (NYT) and Washington Post (WaPo) (Gruley and Duvall 2012; Hawk 1992; Myers, Klak, and Koehl 1996; Thompson 2007). The narrative was one that did not seek to put the genocide into context by linking it to an on-going hostilities that had exacerbated following the 1990 Tutsi incursion or, as suggested by Komola (2007) global economic events such as the drastic fall in commodity prices- like plummeting prices of coffee. Instead Rwanda was framed as timeless and ahistorical, fanned by ancient tribal hatreds while simultaneously also being spontaneous (Harrow 2005; Hintjen 1999; Myers et al. 1996). This ahistorical and decontextualized approach makes an appearance in the reporting of atrocities in Darfur as well. Initial reports by the NYT and WaPo 
reports on Darfur also relied on the ancient tribal hatreds frame that had been used in Rwanda (Sengupta 2004; Wax 2004). In an analysis of U.S. newspaper articles on Darfur, Gruley and Duvall (2012) find that few journalist, such as Lacey (2004) at NYT, report on Darfur as a conflict about equitable sharing resources and representation in government. Crilly (2010), a journalist himself, points to the fact that journalists have contributed in decontextualizing the Darfur conflict by seeking to relegate "history, geography and identity to footnotes" (107) in the pursuit of headlines that captured the audience.

Alozie (2007) shows that African newspapers, specifically from Kenya and Nigeria, worked to provide context for the Rwanda genocide. He shows that there was an attempt to highlight who the actors were, their motivations and what the genocide meant for the Great Lakes Region. The Daily Nation from Kenya situated the genocide in the context of the peace negotiations that had been going on for several months, "Rwanda had been torn by divisions among ruling Hutus over a peace accord [..] signed in August with rebels from the minority Tutsi tribe last year," (Agencies 1994). The Daily Nation went on to explain the role of ethnicity in the atrocity and pushed back against the negative instrumenatlisation of ethnicity by ethnic entrepreneurs:

What is interesting about tribal tensions is that they are a relatively new phenomenon. In pre-colonial era, Hutus and Tutsis were on equal footing and inter-marriage was common. It was Belgium's modernization and democratization that undermined local elite; tension then rose (Daily Nation 1994)

For Darfur, political context of the conflict was more salient with articles talking about the marginalization Darfur, the conflict between North and South Sudan, the Abuja peace talks etc. The Daily Nation argued that the conflict was "much more complex than an Arab-Black clash"(Ochieng' 2008) and that it was affecting the prospects of peace negotiations between 
Sudan and South Sudan that were taking place in Kenya (Oluoch 2004). The centrality of the government to either conflict is pointed to more by the African newspapers. Journalists in both Kenya and South Africa appeared largely agree that the Sudanese government bears the blame squarely for Darfur but that also, there is a need to understand and appreciate the role played by outside actors such as Chad, Libya, Eritrea:

Sudan and Tchad supported each other's, you... know the, rebels because the Sudanese did the same in Tchad as Tchad is doing in Sudan. So I can see the dynamic there even if the origins are a bit hard to understand [reason for interference by Chad in Darfur] [South African interviewee]

\section{Narrative on Ethnic/tribal hatred}

Another common frame is one that privileges narratives on ethnic/tribal hate over any other explanations. In Rwanda the genocide was largely spoken of as one that was caused by "centuries-old tribal hatred that erupted into an all-out violence for political control" (Lorch 1994). In Darfur both NYT and WaPo privileged ethnicity/tribalism schism that paralleled the narrative during the Rwanda genocide. In both instances, the conflict was defined as centuries old and not anchored in political or economic motives. In an interview with the National Catholic Reporter, Nicholas Kristof defines Darfur as a region with "historical tensions between the Arab tribes and non-African tribes," (Kristof 2006). However, Ray's analysis of African newspapers finds " a tendency to report on the violence [in Darfur] in an oversimplified racialised way that often reveals and anti-Arab bias. A few reports addressed the complex identity politics at work in the violence, and in this way mirrored much of the reportage in western news sources," (2009; 172).

Journalists explain this in primarily two ways. One is a perceived cultural affinity with those defined as 'black African'. The other is that the narrative on ethnic/tribal hatred has been 
constructed in Sudan itself and as such this is reflected in the reporting by journalists:

we often don't consider North Africa or...big chunks of North Africa as 'real' Africa [..] also Sudan, al least the northern part of Sudan, so therefore this kind of divide is very evident in reporting and the way this [the Darfur conflict] is analysed [South African interviewee]

I met a journalist who told me [pause] we have been persecuted for too many centuries. Now we want our land back, and 'these people' [meaning Arabs and Muslims] should go back to where they came from because we too are people who have been wronged by light skinned people, they call them 'the brown colonizers' not white but brown skinned colonizers [Kenyan interviewee]

There was push back, however, amongst other journalists who suggest that the presence of such narratives in African reportage should be understood as a consequence of inadequate funding. This necessitates news organizations relying more on wire services rather than sending their own staff to conduct investigative reporting:

I don't think here [....] we have the capacity [to have their own correspondent always in Sudan]. So when it comes to the coverage of that war [Darfur] we largely depend on the wire agencies. Also, they will have the resources and have the advantage of their agencies operating in this area for a long...long time. [Kenyan interviewee]

\section{Discussion}

What does it mean then when African news organizations do not contextualize atrocity in Africa or rely on narratives of ethnic/tribal hatred? There are several possible answers to this conundrum such as the influence of international institutions on global discourse and how Africans in general learn of events happening in other African countries. There is also the role played by a limited amount of narrative genres available to journalists or the role of collective memory in influencing how an atrocity is reported on. As suggested by Savelsberg and King's (2007) work, a limit on narrative genres available creates a boundary within which levels of narrative innovation is restricted. It could also be a result of already existing narratives on 
ethnicity/tribal hatreds functioning as repositories (Leavy 2007) from which journalists draw. Therefore "centuries-old tribal hatred," (Lorch 1994) and "historical tensions between the Arab tribes and non-African tribes," (Kristof 2006) are influenced by already present narratives and frames about conflict in Africa. They are also, signs, of "cultural/historical/racial differences," (Bhabha 1994:18), that need to be anxiously repeated to reify values held by the audience.

Shome and Hegde (2002) argue that within the global/local nexus, we must appreciate that boundedness of agency to "the politics of identity couched within the structures of gender, nation, class, race [...]," (267). Thus the role of sedimented knowledge from which culture, meaning and our understanding of the world outside of us is made cannot be understated (Hall 1997; Omanga 2011). This is in line with arguments on nation specific traits in influencing how atrocities such as these would be represented (Savelsberg and Nyseth-Brehm 2012). In the case of South Africa, the experience of apartheid influenced how journalists viewed and reported on Darfur:

our implicit support lies with the so-called black Africans for two reasons, the one is uhh the fact that we can associate better with them both because of uhh if you want to call it that uhh political strife a similar political strife that we've had from apartheid in South Africa [South African interviewee]

Moreover, the news will be framed in a manner that is not only congruent to dominant professional norms as suggested by Entman and Rojecki (2010) and Sigal (1973), but also by whether or not journalists employ “words and images highly salient” within society's knowledge structure (Entman 2004:6). Entman (2004) and Hall (2000) both suggest that to understand the news and how it's framed requires one to be attentive to the role of the bureaucratic organization of a news organization, which works to produce news within particular categories. Cook (1998) 
highlights the same when cautioning against reading too much into the strength of journalistic agency, suggesting that it is dangerous to transpose individual motivation of journalists onto the field of journalists as a whole. Moreover, it is important not to lose track of the fact that the newsmaking process is a business which requires organizations to work to make a profit and us such requiring them not stray to far from a formula that works; one that, as was put to me by a South African journalist, targets "the heartstrings" and puts "a human context."

Savelsberg and Nyseth-Brehm (2012) also suggest that a nation's collective memories of traumatic events in their past, such as the influence of Ireland's potato famine and poverty on its coverage of Darfur, will manifest itself in how the atrocity is framed by policy makers and journalists. As was explained by interview participants in South Africa, the memory of apartheid played a large role in how they reported on and understood the atrocities in Darfur. What was unique to South Africa, though, was the fact that there appears to be a feeling of guilt because of the near lack of reporting of the genocide in Rwanda. It also shows the strength of collective memories and national histories and their role in shaping how African media houses by and large represented Rwanda and later Darfur (Mamdani 2001, 2007; Savelsberg and King 2011). As was put it me:

here [South Africa] we pay a lot of attention to Rwanda because it happened around the same time we were having our democratic elections [... so maybe we just have an extreme guilt about that [..] so therefore if you want to create some kind of message about what is happening in Darfur what had happened then you refer to Rwanda its at least a link and I think that's useful [South African interviewee]

The presence of narrative of ethnic/tribal hatred can also be explained as a consequence of editorial pressures. Editors place pressures on journalists which work to produce relative homogeneity within the journalism field (Bourdieu 1999; Benson 1999, 2006). As posited by both Bourdieu (1999) and Martin (2003), pressures within a professional field lead individual enmeshed in them to understand and operate within the "rules of the game." Part of 
understanding these "rules" is by journalists anticipating what their editors will allow to be publish and thus tailor their framing of atrocities to meet this expectation. As a South African participant observed:

These are the kind of battles [how to frame atrocities] we do fight on a regular basis with our editors and even our readers. It's not good or bad, I'm not complaining or anything I'm saying that is the reality of the life we live and it's the life we chose [South African interviewee]

This should not detract from the role played by journalists in the search for the dramatic. The fact that Crilly (2010) actively searched for fresh atrocities by the Janjaweed points to some agency in seeking out sensational stories of Darfur and, I argue, atrocities in general, by journalists. Thus while taking into account the constraints placed on journalists by news organisations and their editors this should not take way from their agency. Hall's (2000) work alerts us to the autonomy journalists have in selecting, researching and producing the news. Schudson (2011) also points out that selecting, highlighting, and shaping of news are part of journalists' work as they disseminate and produce information on issues of general public interest and importance. Journalists do not simply transcribe events that are transparent, rather, they have some latitude in interpreting them according to their personal perspectives and understandings of said events (Gans 1979; Schudson 2011).

As pointed out by Savelsberg and Nyseth-Brehm (2012), the role of international actors such as the International Criminal Tribunal in affecting the framing of Darfur cannot be ignored. They find an increase in the use of a crime frame when talking about Darfur after judicial intervention by the ICC. Hadler and Haller (2011) have also pointed to the importance of global scripts on one's own sense of what is appropriate or not (in their work this is specifically on discourse surrounding recycling). Therefore it would be safe to assume that by employing scripts employed by the UN or the ICC, the task of contextualising was not strictly adhered to. As such, in those 
moments that we find a lack of context being provided what we may be seeing is a reflection of global scripts about Rwanda or Darfur. As highlighted by Styan's (1999) discussion of the journalism field in African countries generally, African countries "get their images of other African countries from a handful of western-based news agencies," (1999; 289). The agencies, most of which are based in large cities like Nairobi, Johannesburg and Lagos, rarely if ever employ local journalist due to an inherent bias towards in-house trained staff versed in the inner workings of the agencies.

Finally, the role of sources used cannot go without mention. While journalists have a wide array of sources from which they got their background information about atrocities, these sources are often from the same milieu, aid workers. Hannerz (2012) and Sigal (1973) caution us on the influential role of sources in shaping the news. As shown by Hallin (1989) news reports are likely to closely resemble the level of agreement amongst the elite sources. In Rwanda, this reliance on sources was critiqued by Hilsum (2007) who argues that it led to a focus on the humanitarian aspects of the conflict rather than the political machinations. Furthermore Entman (2004) and Hallin (1989) both posit that a reliance on sources leads to further cognitive constraints and a limited scope of investigation and range of employed narratives. The role of sources, especially those from humanitarian organizations is also one that journalists struggle with, as was put to me by a participant:

sometimes we rely too heavily on what Human Rights Watch says about something or International Crisis Groups or whatever. I don't generally suspect them of wanting to distort some of the issues that you have mentioned, they don't go there with a pro-U.S. agenda but they have their own limitations I suppose. I guess I should rely a bit more...well ideally you have your own people there, but that's not going to happen. [South African interviewee] 


\section{Conclusion}

Whilst there has been a lot of scholarly interested in representations of Africa and Africans, very little has been done on how Africans represent Africa and Africans. As already mentioned, this silence is even more perplexing when considering how much has been done on representations of atrocity in Africa. Though only just preliminary, the results used here point to interesting trends within the journalism field in Africa. What I hope to have shown is the importance of including African media organisations when looking at the representations of atrocities in Africa and how it problematizes present scholarship on representation. By including them here I argue that it is not enough to argue for the primacy of nation-specific cultural traits or the cultural sediments but rather recognize the matrix of pressures in which individual journalists are at the intersection of. This understanding opens up new and exciting avenues for understanding the politics that are inherent in representations of atrocities (Mahtani 2009; Mamdani 2007; Wenden 2005).

Covering foreign atrocity requires distant reality to be transformed into one that is salient and intelligible by creating conceptual order (Park 1923). Therefore, journalists filter an atrocity through the domestic system of a society's knowledge structure, and with this a reliance on recognizable language and frames becomes paramount for a journalist (Chin-Chuan et al. 2002; Hall 1973; Seaton 1999). Chin-Chuan et. al (2002), Hall (1973) and Moeller (1999) all suggest that ambiguity, and indeterminacy, of social reality abroad is domesticated in an attempt to avoid cognitive dissonance for the audience. This is true for both western and African journalists and audiences. Consequently a Kenyan journalist cannot be assumed to always provide proper context for a mass atrocity in Africa nor is an American or English journalist always going to offer simplistic narratives about the same. 
Notes

${ }^{1}$ Though Savelsberg and Nyseth-Brehm (2012) are the listed authors for this project, it is important to note that the large data collection, and coding, was achieved with the help of a battery of Research Assistants whose contribution to the project cannot go unacknowledged.

${ }^{2}$ This should not be taken to be advocating for a moral equivalence. Some distortions are so insidious that they should be avoided if not highlighted for their ridiculous and outrageous nature. An example of such a distortion is Robert Kaplan's Coming Anarchy or initial coverage of the second Iraqi invasion by the New York Times which portrayed Iraq and Saddam as harboring Al Qaeda and Weapons of Mass Destruction

${ }^{3}$ Gruley and Duvall (2012), Hawk (1992) and Mamdani (2007) have shown that issues like poverty, hunger and disease in Africa are often portrayed as outcomes of 'natural' conditions unique to Africa and Africans. 


\section{References}

Agencies. 1994. "Now Troops Kill Prime Minister.” Daily Nation, April 9.

Alexander, Jeffrey, Ron Eyerman, Bernhard Giesen, Neil Smelser, and Piotr Sztompka. 2004. Cultural Trauma and Collective Identity. Berkeley, California: University of California Press.

Allen, Tim, and Jean Seaton. 1999. "Introduction." Pp. 1-9 in The Media of Conflict: War Reporting and Representations of Ethnic Violence, edited by Tim Allen and Jean Seaton. New York, NY: St. Martin's Press, Inc.

Anon. 1994. "A Catastrophe for Rwanda and Burundi.” Daily Nation.

Asad, Talal. 2007. On Suicide Bombing. New York: Columbia University Press.

Atkinson, Philippa. 1999a. "Deconstructing Media Mythologies of Ethnic War in Liberia." Pp. 192-218 in The Media of Conflict: War Reporting and Representations of Ethnic Violence, edited by Tim Allen and Jean Seaton. New York, NY: St. Martin's Press, Inc.

------. 1999b. "Representations of Conflict in the Western Media: The Manufacture of a Barbaric Periphery." Pp. 102-8 in Culture and Global Change, edited by Tracy Skelton and Tim Allen. London: Routledge.

Benson, Rodney. 1999. "Field Theory in Comparative Context: A New Paradigm for Media Studies." Theory and Society 28:463-98.

------. 2006. “New Media as a 'Journalistic Field': What Bourdieu Adds to New-Institutionalism, and Vice Versa.” Political Communication 23(2).

Berger, Peter, and Thomas Luckmann. 1966. The Social Construction of Reality: A Treatise in the Sociology of Knowledge. New York: Anchor Books.

Bhabha, Homi K. 1994. The Location of Culture. 2012th ed. Routledge.

Bourdieu, Pierre. 1999. On Television. New York: New Press.

Chin-Chuan, Lee, Joseph Man Chan, Zhongdang Pan, and Clement Y.K. So. 2002. Global Media Spectacle: News War over Hong Kong. Albany,NY: State University of New York.

Connerton, Paul. 1989. How Societies Remember. Cambridge University Press.

Cook, Timothy E. 1998. Governing with the News: The News Media as a Political Institution. Chicago: University of Chicago Press.

Durkheim, Emile. 1961. The Elementary Forms of the Religious Life. Mineola, NY: Courier Dover Publications. 
Entman, Robert. 2004. Projections of Projections of Power: Framing News, Public Opinion and US Foreign Policy. Chicago: University of Chicago Press.

Fairclough, Norman. 1992. "Discource and Text: Linguistic and Intertextual Analysis within Discourse Analysis.” Discourse Society 3(2):193-217.

Fine, Gary Alan. 2001. Difficult Reputations: Collective Memories of the Evil, Inept, and Controversial. Chicago: University of Chicago Press.

Gamson, William, David Croteau, William Hoynes, and Theodore Sasson. 1989. "Media Images and the Social Construction of Reality." American Journal of Sociology 95:1-37.

Gans, Herbert J. 1979. Deciding What's News: A Study of CBS Evening News, NBC Nightly News, Newsweek, and Time. Evanston, Illinois: Northwestern University Press.

Gruley, Joel, and Chris Duvall. 2012. "The Evolving Narrative of the Darfur Conflict as Represented in The New York Times and The Washington Post, 2003-2009." GeoJournal 77:27-46.

Grzyb, Amanda. 2010. "Media Coverage, Activism, and Creating Public Will for Intervention in Rwanda and Darfur.” Pp. 61-94 in The World and Darfur: International Response to Crimes Against Humanity in Western Sudan, edited by Amanda Grzyb. Montreal: McGill-Queen's University Press.

Hadler, Markus, and Max Haller. 2011. "Global Activism and Nationally Driven Recycling: The Influence of World Society and National Contexts on Public and Private Environmental Behavior." International Sociology 26(3):315-45.

Hagan, John, and Wenona Rymond-Richmond. 2009. DARFUR and the Crime of Genocide. Cambridge University Press.

Halbwachs, Maurice. 1992. On Collective Memory. edited by Lewis Coser. Chicago: University of Chicago Press.

Hall, Stuart. 1973. "Encoding and Decoding in the Television Discourse." in Culture, Media and Language, edited by Stuart Hall, Dorothy Hobson, Andrew Lowe, and Paul Willis. London: Hutchinson.

-----. 1997. “The Work of Representation.” Pp. 13-64 in Representation: Cultural Representations and Signifying Practices, edited by Stuart Hall. London: Sage.

------2000. “The Social Production of News.” Pp. 645-52 in Media Studies a Reader, edited by Chas Critcher, Tony Jefferson, John Clarke, and Brian Roberts. New York: New York University Press.

------. 2007. “The Hinterland of Science: Ideology and the Sociology of Knowledge.” Pp. 127-48 in Centre for Comparative Cultural Studies selected working papers, vol. 1, edited by 
Ann Gray, Jan Campbell, Mark Erickson, Stuart Hanson, and Helen Wood. New York, NY: Routledge.

Hallin, Daniel C. 1989. The Uncensored War: The Media and Vietnam. Berkeley: University of California Press.

Hannerz, Ulf. 2012. Foreign News: Exploring the World of Foreign Correspondents. Chicago: University of Chicago Press.

Harrow, Kenneth W. 2005. "“ Ancient Tribal Warfare': Foundational Fantasies of Ethnicity and History." Research in African Literatures 36(2):34-45.

Hawk, Beverly G. 1992. Africa’s Media Image. edited by Beverly G. Hawk. Praeger.

Hilsum, Lindsey. 2007. "Reporting Rwanda: The Media and the Aid Agencies.” Pp. 167-87 in The Media and the Rwanda Genocide, edited by Allan Thompson. Pluto Press.

Hintjen, Helen. 1999. "Explaining the 1994 Genocide in Rwanda." Journal of Modern African Studies 37(2).

Holmquist, Michael. 1983. "The Politics of Representation.” The Quarterly Newsletter of the Laboratory of Comparative Human Cognition 5.

Komola, Isaac. 2007. "The Global Coffee Economy and the Production of Genocide in Rwanda." Third World Quarterly, 28(3).

Kristof, Nicholas. 2006. "The Tragedy of Darfur: Journalist Nicholas Kristoff Talks about Genocide in Sudan and What Can Be Done to End It."

Lacey, Marc. 2004. "Evicted from Camp, Sudan Refugees Suffer in Limbo.” New York Times, August 3.

Leavy, Patricia. 2007. Iconic Events: Media, Politics, and Power in Retelling History. Lexington Books.

Lippmann, Walter. 1922. Public Opinion. Filiquarian Publishing, LLC.

Lorch, Donatella. 1994. “Anarchy Rule Rwanda’s Capital and Drunken Soldiers Roam City.” New York Times, April 14.

Mahtani, Minelle. 2009. "The Racialised Geographies of News Production and Consumption." GeoJournal 74(3):257-64.

Mamdani, Mahmood. 2001. When Victims Become Killers: Colonialism, Nativism, and the Genocide in Rwanda. Princeton, New Jersey: Princeton University Press.

-----. 2007. “The Politics Of Naming: Genocide, Civil War, Insurgency.” London Review of Books 29(8). 
Mannheim, Karl. 1936. Ideology and Utopia. New York, NY: Routledge.

Martin, John. 2003. "What Is Field Theory?” American Journal of Sociology 109(1).

Melvern, Linda. 2006. "Rwanda and Darfur: The Media and the Security Council." International Relations 20(1):93-104.

Mills, C. Wright. 1967. "The Cultural Apparatus.” Pp. 404-20 in Power, politics, and people: The Collected Essays of C. Wright Mills, edited by Irving Horowitz. New York: Oxford University Press.

Myers, Garth, Thomas Klak, and Timothy Koehl. 1996. "The Inscription of Difference: News Coverage of the Conflicts in Rwanda and Bosnia." Political geography 15(1):21-46.

Nyseth-Brehm, Hollie. 2014. "Conditions and Courses of Genocides.” Dissertation, University of Minnesota, Minneapolis Minnesota.

Ochieng', Zachary. 2008. "Conflict Much More Complex than an Arab-Black Clash.” East African, October 8.

Oluoch, Fred. 2004. "How the Conflict Is Affecting Prospects of Peace in S.Sudan." Daily Nation, September 13.

Omanga, Mainye. 2011. "So, What Is Terrorism? How Editorial Cartoons Framed the Nairobi Ebassy Terror Attacks." African Media Review 19(1 \& 2):1-26.

Park, Robert. 1923. "The Natural History of the Newspaper.” American Journal of Sociology 29(3):273-89.

Pendas, Devin Owen. 2006. The Frankfurt Auschwitz Trial, 1963-1965: Genocide, History and the Limits of the Law. Cambridge, England: Cambridge University Press.

Rughani, Pratap. 2010. "Are You a Vulture? Reflecting on the Ethics and the Aesthetics of Atrocity Coverage and Its Aftermath." in Peace Journalism, War and Conflict, edited by Rachard Keeble, John Tulloch, and Florian Zollman. New York: Peter Lang Publishing.

Savelsberg, Joachim, and Ryan King. 2011. American Memories: Atrocities and the Law. New York: Russell Sage Foundation.

Savelsberg, Joachim, and Hollie Nyseth-Brehm. 2012. "Collective Representations of Atrocities and National Identity: The Case of Darfur." Pp. 149-76 in National and Transnational Identities, edited by Markus Hadler and Franz Hoellinger. Chicago: University of Chicago Press.

Schudson, Michael. 2011. The Sociology of News. W W Norton \& Company Incorporated. 1989. “The Sociology of News Production." Media, Culture and Society 11:263-82. 


\section{Seaton, Jean. 1999. "The New 'Ethnic' Wars and the Media."in The Media of Conflict: War} Reporting and Representations of Ethnic Violence, edited by Tim Allen and Jean Seaton. New York, NY: St. Martin's Press, Inc.

Sengupta, Somini. 2004. "War in Western Sudan Overshadows Peace in the South.” New York Times, January 17.

Shapiro, Michael J. 1988. The Politics of Representation: Writing Practices in Biography, Photography, and Political Analysis. University of Wisconsin Press.

Shome, Raka, and Radha Hegde. 2002. "Postcolonial Approaches to Communication: Charting the Terrain, Engaging the Intersections." Communication Theory 12(3).

Sigal, Leon V. 1973. Reporters and Officials: The Organization and Politics of Newsmaking. D. C. Heath.

Steinmetz, George. 2005. "The First Genocide of the 20th Century and Its Postcolonial Afterlives: Germany and the Namibian Ovaherero." Journal of the International Institute 12(2).

-----. 2008. The Devil's Handwriting: Precoloniality and the German Colonial State in Qingdao, Samoa, and Southwest Africa. University of Chicago Press.

Styan, David. 1999. "Misrepresenting Ethiopia and the Horn of Africa? Constraints and Dilemmas Of Current Reporting." in The Media of Conflict: War Reporting and Representations of Ethnic Violence, edited by Tim Allen and Jean Seaton. New York, NY: St, Martin's Press, Inc.

Thompson, Allan, ed. 2007. The Media and the Rwanda Genocide. Pluto Press.

Tuchman, Gaye. 1978. Making News: A Study in the Construction of Reality. New York, NY: Free Press.

Wax, Emily. 2004. “'We Want to Make a Light Babe': Arab Militiamen in Sudan Said to Use Rape as Weapon of Ethnic Cleansing." Washington Post, June 30.

Weimann, Gabriel. 2000. Communicating Unreality: Modern Media and the Reconstruction of Reality. Thousand Oaks, Ca.: Sage Publications.

Wenden, Anita. 2005. "The Politics of Representation: A Critical Analysis of an Al-Jazeera Special Report.” International Journal of Peace Studies 10(2). 
